\title{
Papiloma bucal producido por VPH y su relación con carcinoma
}

\author{
Adel Martínez Martíneza , Rosa Baldiris Ávilab ${ }^{b}$ Antonio Díaz Caballeroc
}

aProfesor Catedrático, Facultad de Odontología, Universidad de Cartagena,

'Campus de la Salud ZaragociIla, Cartagena (Colombia). Profesora Asociada, Facultad de Ciencias Exactas, Universidad de Cartagena, Campus de la Salud Zaragocilla, Cartagena (Colombia).

'Profesor Titular, Facultad de Odontología, Universidad de Cartagena, Campus de la Salud Zaragocilla, Cartagena (Colombia).

Correspondencia: Autor de correspondencia: Adel Martínez Martínez, Facultad de

Odontología de la

Universidad de Cartagena,

Campus de la Salud Zaragocilla, Cartagena (Colombia),

Telf.: 057+5+6698172, Ext. 110.

Correo electrónico:

adelmartinez@hotmail.com, adiazc1@unicartagena.edu.co

Recibido el 9 de marzo de 2012.

Aceptado para su publicación el 29 de abril de 2012.

\section{RESUMEN}

El virus del papiloma humano (VPH) es el responsable de múltiples manifestaciones en boca, las cuales generalmente se caracterizan por lesiones vegetantes, verrugosidades o lesiones papulares. La incidencia de la enfermedad en boca ha aumentado ya que el contagio por vía sexual es una de las principales vías de contagio, lo que también permite que cada vez exista un mayor número de diagnósticos de VPH oncogénico en cavidad bucal.

Palabras Clave. Papiloma, Neoplasias de la boca, Virus ADN.

\section{ABSTRACT}

Oral papiloma caused by HPV and its relation to carcinoma

The human papiloma virus (HPV) is responsible for multiple mouth disorders, which are generally characterized by fungating lesions, verrucosity or papular lesions. The incidence of oral disease has increased since sexual transmission is one of the main channels of infection, which also allows there to be an increasingly higher number of diagnoses of oncogenic HPV in the oral cavity.

Key words. Papilloma, Mouth neoplasms, DNA Virus Infections

\section{INTRODUCCIÓN}

El virus papiloma humano (VPH) es un virus desnudo, con unos $55 \mathrm{~mm}$ de diámetro, un núcleo de ADN de doble cadena circular, pertenece a la familia Papilomaviridae ${ }^{1}$. Su genoma está conformado por 7.200 a 8.000 pares de bases con un peso molecular de $5.2 \times 10^{6}$ Daltons, cubierto por una cápside icosahédrica compuesta de 72 capsómeros que lo envuelve ${ }^{2}$. Constituye un grupo viral heterogéneo que posee gran afinidad por los epitelios, es capaz de producir lesiones hiperplasias, papilomatosas y verrugosas tanto en piel como en mucosa, y en los últimos años se demuestra que juega un importante papel en la carcinogénesis². La vía sexual, es la más común para su contagio, es por esto que la infección por VPH es considerada la enfermedad de trasmisión sexual más frecuente en el mundo. Algunos autores consideran que en adultos la principal vía de trasmisión es el sexo oral $^{3}$. Entre las lesiones bucales benignas se incluyen el papiloma bucal, verruga vulgar bucal, condiloma acuminado bucal e hiperplasia epitelial focal (también llamada enfermedad de Heck) ${ }^{4}$, las lesiones premalignas o malignas incluyen la leucoplasia y el carcinoma escamocelular ${ }^{1}$.

En el presente artículo se reporta un caso de paciente con impresión diagnóstica de papiloma bucal asociado a VPH.

\section{OBSERVACIONES CLÍNICAS}

Mujer de 32 años de edad que consulta por lesiones exofíticas repetitivas en comisuras labiales, las cuales no han sido diagnosticadas, ni tratadas adecuadamente, refiere preocupación por su aspecto estético. Niega antecedentes de importancia clínica. La paciente tiene una vida sexual activa, con una sola pareja con la que vive en unión libre, practica sexo genital y oral. 
No se evidencia presencia de lesiones vegetantes en piel de cuello, extremidades y manos.

Se observan lesiones exofíticas de aspecto verrugoso en comisuras labiales derecha e izquierda, de 8 meses de evolución, asintomáticas, firmes, de 1 por 0.5 centímetros de diámetro, base sésil, superficie nodular con apariencia de lesiones que confluyen, no sangrantes, bordes definidos, confinadas a la piel comisural, sin comprometer la mucosa retrocomisural, bordes definidos, con superficie descamativa y costrosa. Se toma biopsia incisional de las lesiones comisurales derechas, arrojando el estudio anatomopatológico el diagnóstico de Verrugas vulgares asociadas a VPH. Se realizó estudio molecular, por PCR, para identificar la presencia de VPH oncogenicos $16-18$, encontrando la presencia de dichos subtipos en las lesiones examinadas. Se realiza escisión quirúrgica con electro bisturí, removiendo toda la lesión, se realizaron controles mensuales en el primer semestre y trimestrales en el año siguiente, observando no recurrencia de las lesiones.

\section{COMENTARIOS}

El cáncer bucal $(\mathrm{CB})$ es una neoplasia maligna de comportamiento agresivo, La mayoría de los CB son del tipo carcinoma escamo celular bucal, representando más del $90 \%$ de todos los cánceres bucales. Esta afección maligna puede estar precedida por lesiones preexistentes, denominadas como desordenes potencialmente malignos de la mucosa o lesiones precancerosas.

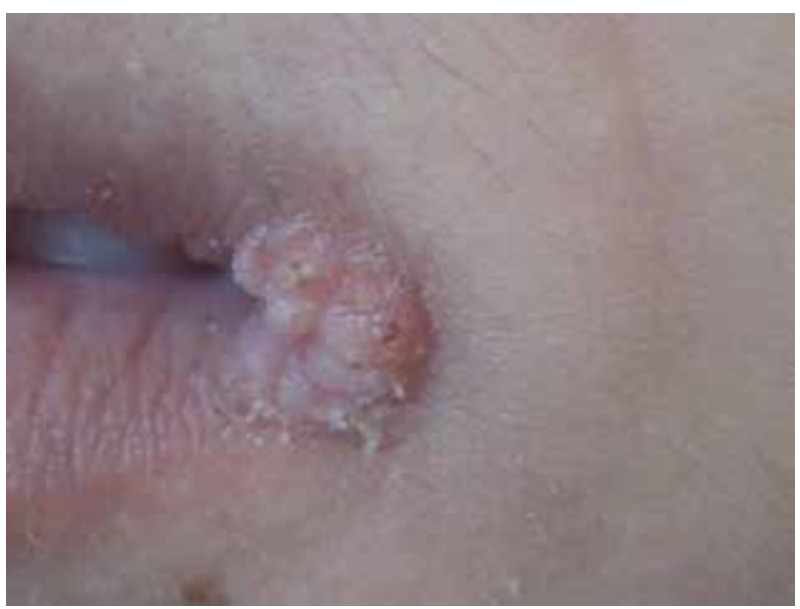

Figura 1. Lesion exofitica, vegetante y cesil. Con superficie rugosa, asintomática. Nótese la lesión en comisura labial característica de infección por VPH.
En Colombia el cáncer es la tercera causa de muerte y el Carcinoma Escamo celular Bucal ocupa el quinto lugar entre todos los cánceres, con una relación hombre/mujer 2:1. Anualmente se presentan aproximadamente 2.000 nuevos casos de cáncer oral, en su mayoría diagnosticados en población mayor de 60 años y raramente en población menor de 40 años; comúnmente se encuentra asociado a factores de riesgo como el tabaco, predisposición genética y el consumo de alcohol, sin embargo, hay factores de riesgo que cada vez se encuentran más relacionados con la aparición de la neoplasia bucal, es el caso de afecciones virales producidas por VPH, especialmente los subtipos considerados de alto riesgo.

\section{BIBLIOGRAFÍA}

1. Ajay Kumar Chaudhary, Shruti Pandya, Ravi Mehrotra, Alok C Bharti, Mangal Singh, Mamta Singh. Comparative study between the Hybrid Capture II test and PCR based assay for the detection of human papillomavirus DNA in oral submucous fibrosis and oral squamous cell carcinoma. Virology Journal 2010, 7:253

2. Silvermann S. Epidemiology. En Oral Cancer. Atlas of clinical oncology. American cancer society. Fifth Edition. London: BC Decker-Hamilton; 2003:1-6.

3. Longworth MS, Laimins LA. Pathogenesis of Human Papillomaviruses in Differentiating Ephitelia. Microbiol Mol Biol Rev 2004; 68(2): 362-72.

4. Ajay Kumar Chaudhary, Shruti Pandya, Ravi Mehrotra, Alok C Bharti, Mangal Singh, Mamta Singh. Comparative study between the Hybrid Capture II test and PCR based assay for the detection of human papillomavirus DNA in oral submucous fibrosis and oral squamous cell carcinoma. Virology Journal 2010, 7:253

5. Silvermann S. Epidemiology. En Oral Cancer. Atlas of clinical oncology. American cancer society. Fifth Edition. London: BC Decker-Hamilton; 2003:1-6.

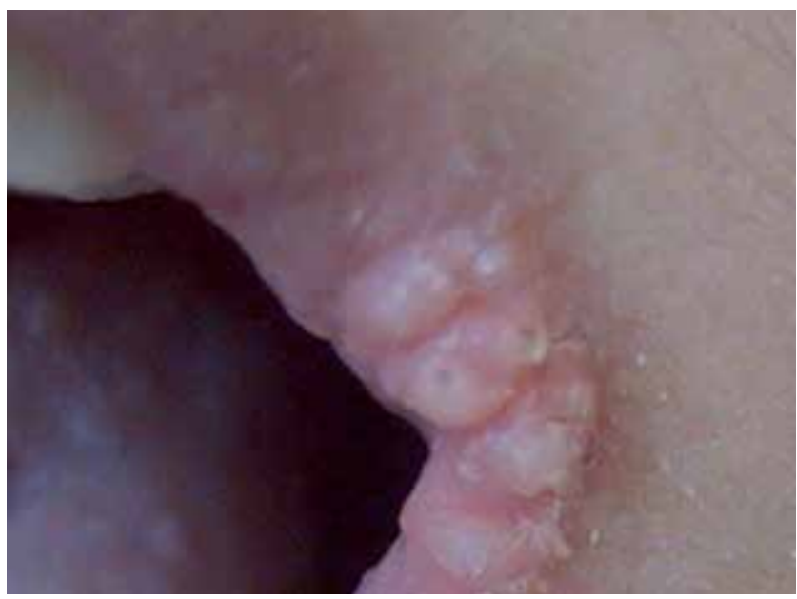

Figura 2. Lesión rugosa y vegetante, con superficie queratinizada en comisura labial. 